\section{SOI: 1.1/TAS DOI: 10.15863/TAS International Scientific Journal Theoretical \& Applied Science}

p-ISSN: 2308-4944 (print) e-ISSN: 2409-0085 (online)

Year: 2017 Issue: 08 Volume: 52

Published: 25.08.2017 http://T-Science.org
Anton Vladimirovich Chistilin Master of the faculty "Public and financial control" at the Financial university under the Government of the Russian Federation

SECTION 19. Management. Marketing. Public administration.

\title{
THE NATURE AND CONTENTS OF THE STRATEGY OF RUSSIAN INNOVATIVE DEVELOPMENT AND ITS FEATURES
}

Abstract: The relevance of the subject of the current article is caused by the fact that this stage of development is characterized by an essential growth of innovative activity worldwide. One of the reasons of this process is explained by a special role of innovations in the development of modern society. The countries with market economy introduce innovations into the number of those main tools which promote increase and strengthening of competitiveness of economic entities. For developing countries, the countries with formed post-industrial economy, innovations are accelerators of economic growth as well as a source of formation of qualitatively new knowledge.

Key words: innovation, innovative activity, economic growth, development strategy.

Language: English

Citation: Chistilin AV (2017) THE NATURE AND CONTENTS OF THE STRATEGY OF RUSSIAN INNOVATIVE DEVELOPMENT AND ITS FEATURES. ISJ Theoretical \& Applied Science, 08 (52): 52-55.

Soi: http://s-o-i.org/1.1/TAS-08-52-7 Doi: crossef https://dx.doi.org/10.15863/TAS.2017.08.52.7

\section{Introduction}

Innovation is the final result of introduction of human intellectual activity, their imagination, creative process, discoveries, inventions and rationalization.

The concept "innovation" (Latin) means change, updating. Innovation itself has two aspects: an innovation and introduction of this innovation in a certain process.

In the work we use a definition of the concept "innovation" which is offered by professor's pupil Chan Kim Gábor Byurt. According to him, innovation is a fight against "painful points" and a mix of non-standard approaches to effective business. Such definition characterize substantial and customer-oriented innovations.

\section{Materials and Methods}

Innovations in a broad sense are understood as profitable use of novelties as in the form of introduction of new technologies as well as new types of production or certain services along with organizational and technical and social and economic solutions of financial, commercial, administrative or other character.

The innovation means using the results of intellectual work as well as the technological developments directed to improvement of social and economic activity in that or in other sphere of public work. Innovations have the following three functions: recovering, investing, stimulating.

Transition of modern society to global informatization demands broad application of information technologies at the modern enterprises as the information and communicative technologies (ICT) allow the enterprises to apply for receiving the innovative status.

At the present stage of social development theimplementation of economic processes at a high level is impossible without introduction of innovative technologies as they make the industry more effective and capable to draw attention of the real experts. Rapid development of innovations in the sphere of science and technology does not allow the Russian economy to stand apart either. Innovative technologies help not only to increase economic efficiency of production, but also to create optimum conditions for increase in profitability of production in the economic plan.

Innovative activity is capable to come up with the highest economic results.

The problems of effective usage of innovative potential, scientific justification of their role in public and economic transformations are of special value and importance. [4, p. 76] The following questions are still debatable: the principles and mechanisms of introduction and management of innovations; tasks of developing the approaches of management of 
innovations and their creation through different projects; determination of efficiency and effectiveness of a managerial system of innovations in the context of achieving steady competitive advantages by the enterprise. In this regard there is a necessity of a competent research of the questions connected with the processes of management of innovations and providing practical tools on adoption of administrative decisions in management of organizations.

So, the value of the term "innovation" depends on a specific goal of a particular research. In the work we consider the principles of introduction of innovative projects and their management.

An innovative project is an object of innovative activity. The concept "innovation" is interpreted by the vast majority of authors from two sides: an innovation as the certain process directed to achievement of result and an innovation as result. The definition of an innovation shows that it without fail has to: novelty;

1) be characterized by essentially qualitative

2) support groups of objects according its extension;

3) have practical focus, to be introduced (that is capable to satisfy market demand) and to have the direction on achievement of a certain effect (to be profitable):

4) to contain a concept of final results.

All this predetermines the maintenance of the main object of innovative activity - an innovative project.

An innovative project is called the planned complex on introduction of production, technical, organizational and economic actions which are united by one general (main) purpose.

An investment project consists of several stages of carrying out the researching which are coordinated in resources, performers and on terms, and is carried out by management.

Other definition says that it is a system of interconnected programs along with the purposes of their achievement making a complex of developmental, research, production, organizational and commercial, financial and some other actions organized and issued by means of project documentation which provides an effective solution of concrete scientific and technical tasks (problems) in quantitative indices whose aim is to promote an innovation.

M.A. Yokhna and V.V. Stadnik consider that the innovative project is a complex of the interconnected actions developed for the purpose of creation, production and introduction of new hi-tech products with resource restrictions.

Thus, the concept "an innovative project" can be considered somewhat as set of measures for achievement of the innovative purposes; as a process of implementation of innovative activity; as a package of the documents causing and describing these actions. [10, p. 213]

It should be noted that development of the innovative project is a long and very expensive process that, in turn, causes the necessity of studying and accounting of a technique of effective project management.

The basis the concept of project management is the view on the project as on the change of any system connected with time expenses and resources, and the process of changes which is carried out by developed rules and procedures is a basis of management of innovative projects as well.

For successful development of the state creation of conditions and methods for effective transformation of human intellectual potential to the intellectual capital is among the main priorities. Such tendency can be tracked both at the level of a separate organization, and at the level of the state.

The main goal of assessment of the intellectual capital is ensuring sustainable development of an organization. The process of introduction of an innovation to the market turns internal innovations into external ones, but there are also such ones which are used in project indicators. One of opportunities of an innovative project are internal innovations of the project which are characterized by motivation of employees, flexibility and constant improvement of the project.

This developed concept of application of innovations in projects can provide to managers the opportunities to make reasonable decisions on project-oriented development both at the enterprise, and in scales of the whole state.

Thus, change of forms of manifestation of a particular system element means economic system transformation.

Globalization becomes a new essential line of international relations. This concept is interpreted in different ways: according to the point of view which prevails, it is impossible to consider any process in society, any action (economic, social, legal, political, military, etc.) in our life only restrictedly, whatever large-scale or private they were. The interdependence and interrelation of separate processes, the phenomena and actions amplify that demands account and assessment of a boomerang effect, both more remote and distant consequences in directly adjacent spheres.

If to talk about innovative politics at the present stage of the Russian Federation, it is necessary to define, first of all, the standard and legal base which regulates an order of realization of this policy. The main document regulating this sphere is the "Strategy of innovative development of the Russian Federation up to 2020" as this strategy sets the main vector in the formation of a political thought of development of innovations in the Russian Federation. 
This Strategy was developed on the basis of the Concept of long-term social and economic development of the Russian Federation for the period till 2020, besides, - according to the Federal Law "About Science and the State Scientific and Technical Policy". The strategy describes both calls, and threats which Russia faces at the moment in the sphere of its innovative development and also defines priorities and purposes in this matter, specifying tools in carrying out state innovative policy. This Concept is based on the results of full comprehensive assessment in the country of its innovative potential and drawing up the scientific and technical long-term forecast.

Key external calls are defined by acceleration of technological development of processes of world economy as well as strengthening competition on a global scale for investments and highly qualified personnel and also for climate changes.

The strategy gives a full assessment of the state in the innovative sphere for the historical modern moment (moderately critical), including all branches of the economy. [5, p. 362] This document is a backbone for all strategic subsequent documents as well as for development of state programs.

\section{Conclusion}

The main objective of the Strategy is the transition of the Russian economy to a new, innovative way of its development up to 2020. It is possible to achieve these objectives according to the following indicators: increase in a share in innovative productions with all total enterprises of innovative plan up to $40-50 \%$ (in relation to a present indicator $10 \%$ ); increase in a share of the Russian Federation in the world markets extending hi-tech goods and services up to $5-10 \%$ approximately in five or even more sectors of economy; increase in an export share for hi-tech Russian goods by 4 times; increase in a share of innovative services and goods in GDP by about 7 times; increase in costs of carrying out the research and development twice and so on. There are also some other documents which belong to innovative policy of the Russian Federation.

Thus, the standard and legal base which regulates an order of implementing the innovative strategy of the Russian Federation, determine by such documents:

- The concept of long-term social and economic development of the Russian Federation up to 2020;

- The strategy of innovative development of the Russian Federation up to 2030;

- Fundamental directions of The Russian policy in the field of development of technologies and science for the period up to 2010 as well as on further prospect;
- The main activities of the Government of the Russian Federation till 2018;

- Priority directions of development of technologies, science and technology of the Russian Federation;

- The strategy of developing the innovations and science in the Russian Federation until 2015;

- The doctrine of development of the Russian science;

- Federal Law "About Science and the State Scientific and Technical Policy".

Thus, the principles of the standard mechanism define realization of innovation policies. The main mission of bodies of the Russian government is the research of subjects of the legislation regarding full implementation of all innovative tasks. As it is noted in legal literature at present time the legislation of the Russian Federation concerning the innovative sphere in many respects has declarative character, and instructive documents quite often contradict with acts.

The essential activization of innovative activity and creation of a civilized market of intellectual property items will be possible only if the coordinated system changes and additions directed to stimulation of innovative activity are made to the regulations of various branches of the legislation.

It is well-known that now various organizations and departments are involved in development of separate aspects of the innovative legislation in tightly departmental interests. The deficiency of the qualified specialists having necessary theoretical knowledge and practical experience of work in the innovative sphere is noted; there are no common basic innovative concepts either.

In Russia two opinions regarding a legislative process in the innovative sphere prevail: creation of common basic innovative law or development of separate laws on various aspects of the innovative activity.

For this purpose, first of all, it is necessary:

- to work out an accurate strategy of innovative policy of the state;

- to formulate the most important innovative projects;

- to develop actions for involvement of the innovative-focused foreign investors;

- to create some mechanisms of legal stimulation of innovative activity.

At the present stage, there are changes in contents and in the nature of the state activity in the connection with the process of world globalization. States more and more deal with such global problems as crime, climate change, approach of deserts, epidemics, poverty and also rational use by various countries of their natural resources. 


\begin{tabular}{|c|c|c|c|c|c|c|}
\hline Impact Factor: & $\begin{array}{l}\text { ISRA (India) } \\
\text { ISI (Dubai, UAE } \\
\text { GIF (Australia) } \\
\text { JIF }\end{array}$ & $\begin{array}{r}=1.344 \\
=0.829 \\
=0.564 \\
=1.500\end{array}$ & $\begin{array}{l}\text { SIS (USA) } \\
\text { PИНЦ (Russia) } \\
\text { ESJI (KZ) } \\
\text { SJIF (Morocco) }\end{array}$ & $\begin{array}{l}=0.912 \\
=0.234 \\
=\mathbf{3 . 8 6 0} \\
=\mathbf{2 . 0 3 1}\end{array}$ & $\begin{array}{l}\text { ICV (Poland) } \\
\text { PIF (India) } \\
\text { IBI (India) }\end{array}$ & $\begin{array}{l}=6.630 \\
=1.940 \\
=4.260\end{array}$ \\
\hline
\end{tabular}

\section{References:}

1. Chernikova A.E. (2016) Osobennosti upravlenija innovacionnymi proektami // Molodoj uchenyj. - 2016. 一 №24. - p. 256-258.

2. Hotjasheva O.M. (2016) Innovacionnyj menedzhment: Uchebnik i praktikum dlja akademicheskogo bakalavriata / O.M. Hotjasheva, M.A. Slesarev. - Ljubercy: Jurajt, 2016. - $326 \mathrm{p}$.

3. Jakobson A.Ja. (2013) Innovacionnyj menedzhment: Uchebnoe posobie / A.Ja. Jakobson. - M.: Omega-L, 2013. - 176 c.

4. Jejhler L.V. (2015) Planirovanie konechnyh rezul'tatov hozjajstvennoj dejatel'nosti gruzovyh avtotransportnyh predprijatij [Jelektronnyj resurs]: monografija / L. V. Jejhler, A. E. Chernikova. - Omsk: SibADI, 2015. - 98 p. - Available: http://elibrary.ru/item.asp?id=25637337 (Accessed: 10.08.2017).

5. Kiseleva V.V., Kolosnicyna M.G. (2016) Gosudarstvennoe regulirovanie innovacionnoj sfery; GU VShJe - Moskva, 2016. - 408 p.

6. Kotljarov N.I., Levchenko L.V. (2013) Globalizacija i regional'naja integracija stran - chlenov Tamozhennogo sojuza. // Jekonomicheskie nauki. -2013. -№7(104). - p. 109.

7. Medynskij V.G. (2013) Innovacionnyj menedzhment: Uchebnik / V.G. Medynskij. M.: NIC INFRA-M, 2013. - 295 p.

8. Rengol'd O.V. (2016) Upravlenie zatratami gruzovogo avtotransportnogo predprijatija $\mathrm{s}$ ispol'zovaniem nalogovogo menedzhmenta [Jelektronnyj resurs] / O. V. Rengol'd // Mezhdunarodnyj nauchnyj zhurnal = International Scientific Journal: sbornik nauch. trudov. - Kiev: [B. i.], 2016. — p. 131-133Available: $\quad$ http://www.internauka.com/uploads/public/14612388706493.pdf (Accessed: 10.08.2017).

9. Rumjancev A.A. (2012) Kommercializacija nauchnoj razrabotki; Nauka - Moscow, 2012. $112 \mathrm{p}$.

10. Tovb A.S. (2010) Upravlenie proektami: standarty, metody, opyt [Tekst] / A. S. Tovb, G. L. Cipes. - 2-e izd. - M.: ZAO «OlimpBiznes», 2010. - 240 p. 